Original Article

\title{
EVALUATION OF ACUTE AND SUB-ACUTE ORAL TOXICITY OF CLINACANTHUS NUTANS LEAVES EXTRACT IN MICE
}

\author{
TRAN THI LINH GIANG1, LE KIM THACH², LE NGUYEN TU LINH'1, VU QUANG DA0¹, TRINH THI BEN¹, BUI DINH \\ THACH $^{1}$
}

\author{
${ }^{1}$ Institute of Tropical Biology, Vietnam Academy of Science and Technology, ${ }^{2}$ Nong Lam University Ho Chi Minh City \\ Email: thachdinhbui@yahoo.com.vn
}

Received: 25 Mar 2020, Revised and Accepted: 22 May 2020

\begin{abstract}
Objective: This study aimed to evaluate acute and sub-acute oral toxicity of ethanol extract of Clinacanthus nutans leaves in Swiss mice.

Methods: Acute oral toxicity study was performed as per OECD-423 guidelines. Sub-acute oral toxicity study was performed as per OECD-407 guidelines. The extract was dissolved in $10 \%$ dimethyl sulfoxide and administered orally, while the control group received only the vehicle.

Results: The acute oral toxicity test on mice showed that this extract was well tolerated up to $\mathrm{LD}_{50} 5000 \mathrm{mg} / \mathrm{kg}$ body weight/day oral dosage level and non-toxic to mice under the present experimental conditions. The sub-acute toxicity study was carried out on mice with the oral dosage of the extract from $100 \mathrm{mg} / \mathrm{kg}-500 \mathrm{mg} / \mathrm{kg}$ body weight/day and $5000 \mathrm{mg} / \mathrm{kg}$ body weight/day for $28 \mathrm{~d}$. The results showed that this extract did not induce death or adverse effects in activity, feed consumption or body weight gain. There were not significant changes in heamotological and biochemical parameters between control and experiment groups.
\end{abstract}

Conclusion: Thus, Clinacanthus nutans leaf has a very low toxicity value.

Keywords: Acute oral toxicity, Clinacanthus nutans, Extract, Sub-acute oral toxicity, Swiss mice

(C) 2020 The Authors. Published by Innovare Academic Sciences Pvt Ltd. This is an open access article under the CC BY license (http://creativecommons.org/licenses/by/4.0/) DOI: http://dx.doi.org/10.22159/ijcpr.2020v12i4.39045. Journal homepage: https://innovareacademics.in/journals/index.php/ijcpr

\section{INTRODUCTION}

The plant-derived herbal compounds have a long history of clinical use, better patient tolerance and acceptance. They are freely available natural compounds that can be safely used to prevent various ailments. Plants became the basis of the traditional medicine system throughout the world for thousands of years and continue to provide mankind with new remedies [1]. Here, we present a research study on a medicinal plant, Clinacanthus nutans, a native of Southeast Asia.

C. nutans belongs to the family of Acanthaceae, is a small shrub that native to tropical Asia countries. It is commonly consumed in the form of herbal tea for the treatment of diabetes mellitus, fever, diarrhoea and dysuria [2]. In recent years, the pharmacological properties of $C$. nutans such as anti-viral, anti-oxidant, antiinflammatory, anti-cancer have been previously reported [3-8].

The purpose of toxicity studies is, 'to determine the effect of an action on a biological system which can be used later to extrapolate the doses and effects on humans' [9]. This data is essential to identify the optimal therapeutic dose and the highest dose up to which the extract can be given, above which lethality would be expected.

Previous studies reported that them ethanolic extract of $C$. nutans at the highest dose of $2500 \mathrm{mg} / \mathrm{kg}$ did not cause any toxic effect on the liver and kidney of mice, thus suggesting its no-observed-adverseeffect level (NOAEL) to be greater than the tested dose [10]. Therefore, the objective of this study is to investigate the possible subacute oral toxicity effect of $C$. nutans ethanolic extract in mice at dose up to $5000 \mathrm{mg} / \mathrm{kg}$ bodyweight for $28 \mathrm{~d}$.

\section{MATERIALS AND METHODS}

\section{Animals}

Outbred Swiss albino mice weighing 18-20 g of either sex, bred in Pasteur Institute, Ho Chi Minh City were procured and used for the study. The animals were allowed food pellets (Pasteur Institute, Ho Chi Minh City) and water ad libitum. Animals were maintained in control conditions (12 h: $12 \mathrm{~h}$ dark and light cycle and room temperature).

\section{Preparation of the extract}

Leaves of $C$. nutans (1 y old) were collected from the Institute of Tropical Biology, Vietnam Academy of Science and Technology. Our Department of Botanical Museum has identified the plant. They were cut into small pieces and dried in Laboratory drying oven at 50 ${ }^{\circ} \mathrm{C}$. They were then crushed into a course powder using a laboratory grinding mill with ring sieve, size $0.25 \mathrm{~mm}$. Maceration extraction of C. nutans in ethanol solvent followed by drying at $50{ }^{\circ} \mathrm{C}$ resulted in an average extract efficacy of $13 \%$. The extract was stored at $-20^{\circ} \mathrm{C}$.

\section{Acute toxicity studies}

Acute oral toxicity study was performed as per OECD-423 guidelines [11]. The mice were divided into two groups: a control group and a treatment group $(\mathrm{n}=10)$. The extract was dissolved in $10 \%$ dimethyl sulfoxide and administered orally at a single dose of 5000 mg kg-1 body weight, while the control group received only the vehicle. Mice were fasted prior to conducting the experiment (only food but not water was withheld for $4 \mathrm{~h}$ ). Following the period of fasting, the mice were weighed and the test substance was administered orally at a single dose, after which the food may be withheld for a further 1-2 h. A dose of $5000 \mathrm{mg} / \mathrm{kg}$ body weight was given to the first mouse then the clinical signs (changes in physical appearance, skin, pain, stress, abdominal contraction) and mortality were observed throughout the first hour, then every hour for $3 \mathrm{~h}$ and finally periodically until48 $\mathrm{h}$. If the animal survived, additional animals will be given the same $5000 \mathrm{mg} / \mathrm{kg}$ dose sequentially at $48 \mathrm{~h}$ intervals. All of the experimental animals were monitored for apparent signs of toxicity for the 14 consecutive days, while the number of died mice within the study period was noted and subjected to necropsies. All mice were weighed on the 7 th and 14 th days after administration.

\section{Sub-acute toxicity studies}

Sub-acute oral toxicity study was performed as per OECD-407 guidelines [12]. The mice were divided into seven groups $(n=10)$, and their weights were measured. The extract was dissolved in $10 \%$ 
DMSO, and administered orally at single doses of 100, 200, 300, 400, 500 and $5000 \mathrm{mg} / \mathrm{kg} / \mathrm{d}$ for $28 \mathrm{~d}$, at a dosing volume of $10 \mathrm{ml} / \mathrm{kg}$ body weight, while the control group received only the vehicle. The animals were observed daily for their physiological and behavioral changes (i.e. signs of toxicity, mortality and the bodyweight changes). The body weights of the animals were recorded once a week throughout the study period. Blood samples were obtained from tail incision, transferred into EDTA-containing and nonheparinized tubes. Blood with EDTA-containing tube was used immediately for hematological parameters while for a nonheparinized tube, it was allowed to clot under room temperature for $15-30 \mathrm{~min}$ before being centrifuged at $3000 \mathrm{x} \mathrm{g}$ at $4{ }^{\circ} \mathrm{C}$ for $10 \mathrm{~min}$ using a centrifuge machine. The serum obtained was stored at $-20^{\circ} \mathrm{C}$ until further analysis of biochemical parameters. The animals were then sacrificed while organs such as spleen, heart, liver, kidneys, lungs were removed, rinsed in $0.9 \%$ saline and weighed individually.

\section{Hematological and biochemical analysis}

Hematology and biochemical analysis were performed at Medic Medical Center-Hoa Hao Medic Company Limited, HCMC, Vietnam. The hematological parameters, which comprised of hemoglobin (Hb), hematocrit (Hct), total red blood cell (RBC) count, total white blood cell (WBC) count, total platelet count (PLT) were performed using an automated hematology analyser (Siemens Advia ${ }^{\circledR}$ 2120i,Siemens, Germany).

The biochemical analysis tests were performed using an automated chemistry analyser (Abbott ${ }^{\mathrm{T} M}$ Alinity ${ }^{\mathrm{TM}}$ Systems, Abbott, US), for biochemical enzymes 'level (i.e. alanine aminotransferase (ALT), alkaline phosphatase (ALP), aspartate aminotransferase (AST), creatinine, total bilirubin, total protein, albumin, glucose and cholesterol).

\section{Statistics}

All data were expressed as mean $\pm S D(n=10)$. The data were analyzed by Student's t-test and one way ANOVA using stat graphics Centurion XV. Differences between groups were considered to be statistically significant at $\mathrm{P}<0.05$.

\section{RESULTS AND DISCUSSION}

\section{Acute toxicity}

All the mice that received $5000 \mathrm{mg} / \mathrm{kg}$ of ethanol leaves extract of $C$. nutans did not show any toxic signs and abnormal behavioural changes post $72 \mathrm{~h}$ of $C$. nutans treatment and during $14 \mathrm{~d}$ observation duration. In additional tothat, $C$. nutans treated mice in this study showed no significant effect on body weight after $14 \mathrm{~d}$ observation period (table 1). From the results obtained, the exact $\mathrm{LD}_{50}$ value could not be determined due to no mortality was observed. However, it is believed that the $\mathrm{LD}_{50}$ of ethanol leaves extract of $C$. nutans is greater than $5000 \mathrm{mg} / \mathrm{kg}$ in mice. Based on the classification of chemical toxicity as described in the OECD 423 guideline, the toxic profile of $C$. nutans is classified as closely to category 5 which is low acute toxicity hazard [11]. Our study was not different from the toxicological study on $C$. nutans carried out by Zakaria et al. in $\mathrm{LD}_{50}$ value [10].

Table 1: Effect of ethanol leaves extract of $C$. nutans on body weight changes and mortality in mice

\begin{tabular}{lllll}
\hline Group (mg/kg) & \multicolumn{2}{l}{ Body weight (g) } & \% Mortality \\
\cline { 2 - 4 } & 0D & 7D & $33.67 \pm 1.75$ & 0 \\
\hline Control & $21.17 \pm 3.25$ & $32.00 \pm 2.10$ & $32.33 \pm 2.42$ & 0 \\
Extract (5000) & $22.00 \pm 1.67$ & $29.67 \pm 2.42$ & & 0 \\
\hline
\end{tabular}

Value $=$ mean \pm standard deviation; $\mathrm{n}=10$. Analyzed using LSD's test

\section{Sub-acute toxicity}

\section{General observations}

Throughout the $28 \mathrm{~d}$ feeding study, there were no clinical signs or effects on survival that could be attributed to the administration of ethanol leaves extract of $C$. nutans in mice.

\section{Body weights}

Any alteration in body weight is believed to be associated with adverse effects of drugs and chemicals [13]. The reduction in body weight exceeding $10 \%$ of initial body weight and internal organ weights are considered as a simple and sensitive index of toxicity following exposure to potentially toxic substances [10]. There was no reduction of body weights were observed between the treated and control groups (table 2). Thus evidencing that $C$. nutans leaves extract didn't cause metabolism reduction in the test animals.

\section{Organ weights}

In this study, the results displayed non-significant changes for organ/body weight ratios of mice in all treated groups as compared to the control (table 3). In general, any change in the liver and kidney weight might be related to the organs injury, including swelling, atrophy or hypertrophy [14]. However, the results still need to be further validated by biochemical analysis assessment to confirm on the findings.

\section{Hematological analysis}

Analysis on hematological parameters are often employed to determine the safety profile and influence of foreign compounds, including plant extracts, on the blood constituents as well as blood-related functions in humans. Such assessment on the blood is crucial and the results thereof can be harnessed to establish how pharmacologically safe an agent is, on the well being of humans. The parameters investigated in this study are useful indices in ascertaining the toxic potentials of botanicals in living systems [15]. There were no statistically significant changes in hematology parameter in mice (tables 4). Data showed that hematology parameters, such as Hb, RBC, WBC and PTL were not significantly affected by ethanol leaves extract of $C$. nutans $(\mathrm{P}>0.05)$.

Table 2: Sub-acute (28 d treatment) effect of ethanol leaves extract of $C$. nutans on body weights in mice

\begin{tabular}{|c|c|c|c|c|c|}
\hline \multirow[t]{2}{*}{ Group (mg/kg) } & \multicolumn{5}{|c|}{ Bodyweight (g) } \\
\hline & OD & 7D & 14D & 21D & 28D \\
\hline Control & $18.80 \pm 1.30$ & $19.00 \pm 1.22$ & $19.60 \pm 1.52$ & $20.40 \pm 1.82$ & $20.80 \pm 1.48$ \\
\hline Extract(100) & $18.20 \pm 0.45$ & $18.60 \pm 0.89$ & $19.60 \pm 1.14$ & $20.20 \pm 1.48$ & $21.80 \pm 1.64$ \\
\hline Extract (200) & $18.80 \pm 1.09$ & $18.80 \pm 0.84$ & $20.00 \pm 0.71$ & $20.40 \pm 1.52$ & $21.40 \pm 2.30$ \\
\hline Extract (300) & $19.00 \pm 1.00$ & $20.67 \pm 2.31$ & $22.00 \pm 1.00^{*}$ & $23.30 \pm 1.15^{*}$ & $26.00 \pm 2.00^{* *}$ \\
\hline Extract (400) & $19.80 \pm 2.94$ & $21.00 \pm 2.55$ & $22.00 \pm 2.65^{*}$ & $23.20 \pm 1.79^{*}$ & $25.60 \pm 1.34^{* *}$ \\
\hline Extract (500) & $19.60 \pm 2.70$ & $21.20 \pm 3.11$ & $22.80 \pm 3.11^{*}$ & $23.60 \pm 2.88^{*}$ & $25.80 \pm 2.77^{* *}$ \\
\hline Extract (5000) & $19.40 \pm 1.14$ & $20.00 \pm 1.87$ & $20.40 \pm 2.07$ & $21.60 \pm 2.30$ & $24.40 \pm 2.97^{* *}$ \\
\hline
\end{tabular}

Value $=$ mean \pm standard deviation; $\mathrm{n}=10$. Analyzed using LSD's test. Significantly different from control: ${ }^{*} \mathrm{p}<0.05,{ }^{* *} \mathrm{p}<0.01$ 
Table 3: Sub-acute ( $28 \mathrm{~d}$ treatment) effect of ethanol leaves extract of $C$. nutans on organ weights in mice

\begin{tabular}{|c|c|c|c|c|c|c|c|c|}
\hline \multicolumn{2}{|c|}{ Relative organ weights } & \multirow[t]{2}{*}{ Control } & \multicolumn{6}{|c|}{ Extract (mg/kg body weight) } \\
\hline & & & 100 & 200 & 300 & 400 & 500 & 5000 \\
\hline Organ/body & Liver & $4.52 \pm 0.31$ & $4.40 \pm 0.36$ & $4.45 \pm 0.79$ & $3.89 \pm 0.57$ & $4.00 \pm 0.56$ & $3.87 \pm 0.18$ & $4.45 \pm 0.49$ \\
\hline \multirow{4}{*}{ weight ratio (\%) } & Kidney & $1.20 \pm 0.14$ & $1.19 \pm 0.14$ & $1.18 \pm 0.18$ & $1.02 \pm 0.13$ & $1.02 \pm 0.15$ & $1.01 \pm 0.15$ & $1.06 \pm 0.13$ \\
\hline & Heart & $0.50 \pm 0.05$ & $0.49 \pm 0.06$ & $0.48 \pm 0.08$ & $0.44 \pm 0.03$ & $0.44 \pm 0.03$ & $0.44 \pm 0.02$ & $0.46 \pm 0.03$ \\
\hline & Spleen & $0.69 \pm 0.38$ & $0.77 \pm 0.45$ & $0.86 \pm 0.23$ & $0.56 \pm 0.14$ & $0.66 \pm 0.25$ & $0.64 \pm 0.23$ & $0.96 \pm 0.44$ \\
\hline & Lung & $0.85 \pm 0.44$ & $0.66 \pm 0.13$ & $0.87 \pm 0.34$ & $0.67 \pm 0.06$ & $0.81 \pm 0.29$ & $0.77 \pm 0.17$ & $0.80 \pm 0.14$ \\
\hline
\end{tabular}

Value $=$ mean \pm standard deviation; $n=10$. Analyzed using LSD's test

Table 4: Sub-acute (28 d treatment) effect of ethanol leaves extract of $C$. nutans on hematological parameters in mice

\begin{tabular}{|c|c|c|c|c|c|c|c|}
\hline \multirow[t]{2}{*}{ Parameters } & \multirow[t]{2}{*}{ Control } & \multicolumn{6}{|c|}{ Extract (mg/kg body weight) } \\
\hline & & 100 & 200 & 300 & 400 & 500 & 5000 \\
\hline WBC $\left(\mathrm{x} 10^{9} / \mathrm{l}\right)$ & $12.18 \pm 1.21$ & $10.84 \pm 1.07$ & $12.72 \pm 1.33$ & $11.48 \pm 1.40$ & $10.90 \pm 1.42$ & $11.73 \pm 1.96$ & $11.71 \pm 1.82$ \\
\hline $\mathrm{RBC}\left(\mathrm{x} 10^{9} / \mathrm{l}\right)$ & $8.09 \pm 0.40$ & $7.93 \pm 0.13$ & $8.16 \pm 0.39$ & $8.02 \pm 0.43$ & $8.09 \pm 0.42$ & $8.06 \pm 0.36$ & $8.05 \pm 0.42$ \\
\hline PLT $\left(\times 10^{9} / \mathrm{l}\right)$ & $913.00 \pm 153.68$ & $888.60 \pm 142.47$ & $841.20 \pm 84.03$ & $1000.40 \pm 160.80$ & $941.20 \pm 197.98$ & $811.40 \pm 203.52$ & $879.60 \pm 160.64$ \\
\hline $\begin{array}{l}\text { Hemoglobin } \\
(\%)\end{array}$ & $13.78 \pm 0.66$ & $11.80 \pm 0.98$ & $14.28 \pm 1.21$ & $13.66 \pm 1.90$ & $13.16 \pm 2.30$ & $12.56 \pm 3.29$ & $12.40 \pm 3.52$ \\
\hline $\begin{array}{l}\text { Hematocrit } \\
(\mathrm{g} / \mathrm{dl})\end{array}$ & $42.76 \pm 12.03$ & $40.08 \pm 5.69$ & $49.24 \pm 4.50$ & $47.04 \pm 4.71$ & $45.02 \pm 3.58$ & $42.30 \pm 8.74$ & $42.20 \pm 7.81$ \\
\hline
\end{tabular}

Value = mean \pm standard deviation; $\mathrm{n}=10$. Analyzed using LSD's test

\section{Biochemical analysis}

Liver and kidney are the two main organs for investigation in oral toxicity study. For the liver function test, four serum hepatic biochemical parameters, namely alanine aminotransferase (ALT), alkaline phosphatase (ALP), aspartate aminotransferase (AST) and total bilirubin were analyzed in this study. AST and ALT are common markers used to diagnose hepatocyte integrity. On the other hand, increases in the serum ALP and bilirubin levels would indicate the presence of cholestasis [16]. An increase in the level of serum proteins is a sign of tissue injury. The determination of serum proteins such as albumin can act as a criterion to assess the synthetic capacity of the liver since nearly all are synthesized in hepatocytes. A reduction in serum proteins, therefore, tends to reflect an occurrence of chronic damage [10].

Table 5: Sub-acute (28 d treatment) effect of ethanol leaves extract of $C$. nutans on biochemical parameters in mice

\begin{tabular}{|c|c|c|c|c|c|c|c|}
\hline \multirow[t]{2}{*}{ Parameters } & \multirow[t]{2}{*}{ Control } & \multicolumn{6}{|c|}{ Extract (mg/kg body weight) } \\
\hline & & 100 & 200 & 300 & 400 & 500 & 5000 \\
\hline AST (U/l) & $189.16 \pm 6.93$ & $187.44 \pm 9.59$ & $188.30 \pm 12.00$ & $191.32 \pm 8.63$ & $192.82 \pm 9.44$ & $190.84 \pm 9.31$ & $190.12 \pm 12.19$ \\
\hline $\operatorname{ALT}(\mathrm{U} / \mathrm{l})$ & $62.33 \pm 5.69$ & $61.88 \pm 5.17$ & $66.60 \pm 5.18$ & $60.15 \pm 5.06$ & $61.57 \pm 7.43$ & $66.87 \pm 7.38$ & $62.06 \pm 8.27$ \\
\hline $\operatorname{ALP}(\mathrm{U} / \mathrm{l})$ & $147.40 \pm 25.95$ & $136.40 \pm 19.79$ & $140.20 \pm 30.73$ & $145.40 \pm 25.79$ & $151.40 \pm 18.02$ & $156.20 \pm 23.31$ & $134.20 \pm 31.58$ \\
\hline Total bilirubin (mg/dl) & $0.16 \pm 0.01$ & $0.16 \pm 0.01$ & $0.16 \pm 0.01$ & $0.16 \pm 0.01$ & $0.15 \pm 0.00$ & $0.16 \pm 0.01$ & $0.15 \pm 0.00$ \\
\hline Total protein $(\mathrm{g} / \mathrm{dl})$ & $6.88 \pm 0.39$ & $6.94 \pm 0.76$ & $7.46 \pm 0.67$ & $7.29 \pm 0.90$ & $6.87 \pm 0.11$ & $7.02 \pm 0.60$ & $6.96 \pm 0.37$ \\
\hline Albumin (g/dl) & $4.48 \pm 0.20$ & $4.41 \pm 0.24$ & $4.39 \pm 0.25$ & $4.54 \pm 0.31$ & $4.32 \pm 0.59$ & $4.54 \pm 0.29$ & $4.39 \pm 0.40$ \\
\hline Glucose (mmol/l) & $8.83 \pm 1.20$ & $8.21 \pm 1.57$ & $7.45 \pm 2.24$ & $7.29 \pm 0.52$ & $8.02 \pm 1.86$ & $7.97 \pm 0.89$ & $9.00 \pm 0.62$ \\
\hline Cholesterol (mmol/l) & $3.96 \pm 0.51$ & $3.75 \pm 0.30$ & $4.09 \pm 0.27$ & $4.20 \pm 0.55$ & $3.70 \pm 0.71$ & $3.81 \pm 0.49$ & $3.71 \pm 0.35$ \\
\hline Creatinin (mg/dl) & $0.32 \pm 0.04$ & $0.33 \pm 0.04$ & $0.33 \pm 0.02$ & $0.35 \pm 0.01$ & $0.34 \pm 0.03$ & $0.33 \pm 0.03$ & $0.32 \pm 0.06$ \\
\hline
\end{tabular}

Value = mean \pm standard deviation; $n=10$. Analyzed using LSD's test

For kidney function tests, serum renal biochemical parameter, namely creatinine, was analysed in this study. Blood serum contains a number of organic constituents such as glucose, protein, bilirubin, cholesterol and enzymes whose concentrations vary with changes in the physiological state. Serum enzymes, especially ALT and AST, are often considered as sensitive indicators to adverse drug effects or to the presence of disease [17]. From the results obtained, all doses of ethanolic extract of $C$. nutans leaves ranging from 100 to $500 \mathrm{mg} / \mathrm{kg}$ bw and $5000 \mathrm{mg} / \mathrm{kg}$ bw showed no significant influence on all serum biochemical parameters when comparing all treated groups to the control group (table 5), indicating that $C$. nutans leaves showed no substancial toxic effect on mice liver and kidney. These results are in agreement with some previous reports $[2,10,18]$.

\section{CONCLUSION}

The acute and sub-acute toxicity studies showed no treatmentrelated signs of toxicity or mortality. Sub-acute toxicity did not induce any biochemical, hematological, anatomica signs of toxicity. Therefore, the $\mathrm{LD}_{50}$ for the acute toxicity study was greater than $5000 \mathrm{mg} / \mathrm{kg}$ while for the sub-acute toxicity study and the NOAEL was greater than $5000 \mathrm{mg} / \mathrm{kg} /$ day.

\section{ACKNOWLEDGMENT}

This work was supported by Ho Chi Minh City Department of Science and Technology, Vietnam Academy of Science and Technology.

\section{FUNDING}

Nil

\section{AUTHORS CONTRIBUTIONS}

All the authors have contributed equally.

\section{CONFLICT OF INTERESTS}

Declare none

\section{REFERENCES}

1. Paul J, Gnanam R, Jayadeepa R, Arul L. Anticancer activity on graviola, an exciting medicinal plant extract vs various cancer cell lines and a detailed computational study on its potent anticancerous leads. Curr Top Med Chem 2013;13:1666-73. 
2. Png XW, Akowuah GA, Chin JH. Acute oral toxicity study of Clinacanthus nutans in mice. IJPSR 2012;3:4202-5.

3. Pannangpetch $\mathrm{P}$, Laupattarakasem $\mathrm{P}$, Kukongviriyapan V, Kukongviriyapan U, Kongyingyoes B, Aromdee C. Antioxidant activity and protective effect against oxidative hemolysis of Clinacanthus nutans (Burm. f) lindau. Songklanakarin J Sci Technol 2007;29:1-9.

4. Wanikiat P, Pathong A, Sujayanon P, Yoosook C, Rossi AG, Reutrakul V. The anti-inflammatory effects and the inhibition of neutrophil responsiveness by Barleria lupulina and clinacanthusnutans extracts. J Ethnopharmacol 2008;116:234-44.

5. Sakdarat S, Shuyprom A, Pientong C, Ekalaksananan T, Thongchai S. Bioactive constituents from the leaves of clinacanthus nutans lindau. Bioorganic Med Chem 2009;17:1857-60.

6. Sittiso S, Ekalaksananan T, Pientong C, Sakdarat S, Charoensri Nand Kongyingyoes B. Effects of compounds from Clinacanthus nutans on dengue virus type 2 infection. Srinagarind Med J 2010;25:272-5.

7. Yong YK, Tan JJ, Teh SS, Mah SH, EE GCL, Chiong HS, et al. Clinacanthus nutans extracts are antioxidant with antiproliferative affect on cultured human cancer cell lines. Evid Based Complement Alternat Med 2013;1-8. DOI:10.1155/2013/462751

8. Arullappan S, Rajamanickam P, Thevar N, Kodimani CC. In vitro screening of cytotoxic, antimicrobial and antioxidant activities of Clinacanthus nutans (Acanthaceae) leaf extracts. Trop J Pharm Res 2014;13:1455-61.
9. Barle E, Looser R, Erne M, Bechter R. The value of acute toxicity testing of pharmaceuticals for estimation of human response. Regul Toxicol Pharmacol 2012;62:412-8.

10. Zakaria ZA, Rahim MHA, Mohtarrudin N, Kadir AA, Cheema MS, Ahmad Z, et al. Acute and sub-chronic oral toxicity studies of methanol extract of Clinacanthus nutans in mice. Afr J Tradit Complement Altern Med 2016;13:210-22.

11. OECD Guidelines for the testing of chemicals. Acute oral toxicity-acute toxic class method, OECD; 2001. p. 423.

12. OECD Guidelines for the testing of chemicals. Repeated dose 28 d oral toxicity study in rodents, OECD; 2008. p. 407.

13. El J, Israili ZH. Acute and chronic toxicological studies of Ajuga iva in experimental animals. J Ethnopharmacol 2004;91:43-50.

14. Amresh G, Nath P, Venkateswara C. Toxicological screening of traditional medicine laghupatha (Cissampelos pareira) in experimental animals. J Ethnopharmacol 2008;116:454-60.

15. Saheed S, Oladipipoa AE, Abdulazeez AA, Olarewajua SA, Ismailaa NO, Emmanuel IA, et al. Toxicological evaluations of Stigma maydis (corn silk) aqueous extract on hematological and lipid parameters in wistar rats. Toxicol Rep 2015;2:638-44.

16. Xiu WP, Gabriel AA, Jin HC. Evaluation of the sub-acute oral toxic effect of methanol extract of Clinacanthus nutans leaves in rats. J Acute Disease 2013;2:29-32.

17. Malini, Vanithakumari. Rat toxicity studies with $\beta$-sitosterol. J Ethnopharmacol 1990;28:221-34.

18. Farsi E, Esmailli K, Shafaei A, Moradi KP, Al Hindi B, Khadeer Ahamed MB, et al. Mutagenicity and preclinical safety assessment of the aqueous extract of Clinacanthus nutans leaves. Drug Chem Toxicol 2016;545:1-13. 